\title{
Conformity to gender stereotypes, motives for riding and aberrant behaviors of French motorcycle riders
}

Cécile Coquelet (Corresponding author)

5 IFSTTAR-TS2/LMA

304 chemin de la Croix Blanche

13300 Salon de Provence - France

and

Aix-Marseille University

10

ISM UMR 7287

13288 Marseille Cedex 09 - FRANCE

+33490577980

cecile.coquelet@ifsttar.fr

15 Marie-Axelle Granié

IFSTTAR-TS2/LMA

304 chemin de la Croix Blanche

13300 Salon de Provence - FRANCE

20 Jean Griffet

Aix-Marseille University

ISM UMR 7287

13288 Marseille Cedex 09 - FRANCE 


\title{
Conformity to gender stereotypes, motives for riding and aberrant behaviors of French motorcycle riders
}

\begin{abstract}
As sex differences are very pronounced in motorcycle crashes, both in terms of number and severity, the present study aims to determine the relationship between gender, motives for riding a motorcycle, and risk-taking behaviors among motorcyclists. Declared aberrant behaviors, conformity to gender stereotypes and motives to ride a motorcycle were investigated among 2,262 riders of heavy motorcycles, through an Internet survey. Ages ranged from 18 to 78 years, $10.5 \%$ of the respondents were women. Results revealed the new scale on motives for riding a motorcycle was effective and allowed to show that competition motives were associated to masculinity, low femininity and youth. They also showed that maleness, masculinity, youth and competition motives were predictors of violations and femaleness and low masculinity were predictors of lapses. Furthermore, competition motives were also mediators between masculinity and aberrant behaviors, except for personal protective equipment negligence. This study gives new knowledge on the relationship between conformity to gender stereotypes, motivations and the behaviors of riders of heavy motorcycles. Results can be useful for adapting prevention campaigns to the small sub-groups that are the more at risk in the motorcyclists' population.
\end{abstract}




\section{INTRODUCTION}

In many European countries, powered two-wheelers (PTW, include light and heavy motorcycles) are the vehicle category where road risk is the greatest. Despite a significant decrease in the number of fatal crashes (divided by three between 2000 and 2013) (ONISR, 2001, 2015), the risk of exposure to a road crash with a PTW is the highest in the French vehicle fleet. In France, in 2013, PTW riders accounted for $19.3 \%$ of fatalities, whereas they represented only $1.3 \%$ of the whole road traffic (ONISR, 2015). The risk of dying in a road crash is 23 times higher for the PTW riders than for car drivers (ONISR, 2015).

The number of female riders has greatly increased in the last decade: in 2012, they represented $5 \%$ of riders of heavy motorcycle (HM, motorcycles over $125 \mathrm{cc}$, which reque a specific license, the A license, to ride this motorcycle category) and 10\% in 2012 (ONISR, 2015). Female riders were less involved in PTW injury crashes than males and especially in fatal crashes: whereas they now represented $25 \%$ of the PTW rider population (FFSA \& GEMA, 2012), they represented only 3\% of the riders of PTW involved in a fatal crash (ONISR, 2017).

In 2015, it was observed that French riders between 18 and 34 years old were the riders population the most involved in fatal and injury crashes: they represented $50 \%$ of the riders involved in a fatal crash and $45 \%$ of the injured riders due to a road crash, when they represented only $20 \%$ of the whole rider's population (ONISR, 2016). Researchers showed that young drivers tended to declare riskier behaviors than more experienced drivers (Aberg \& Rimmö, 1998; Lassarre, Coquelet, Hoyau, \& Lahatte, 2008; Obriot-Claudel \& Gabaude, 2004; Özkan \& Lajunen, 2006). Others studies also showed that the youngest drivers committed more violations (Aberg \& Rimmö, 1998; de Winter \& Dodou, 2010; Guého, Granié, \& Abric, 2014; Obriot-Claudel \& Gabaude, 2004; Özkan \& Lajunen, 2005, 2006; Parker, Reason, Manstead, \& Stradling, 1995) and more errors (de Winter \& Dodou, 2010; Guého et al., 2014). A study on riders, based on the theory of Reasoned Action and the Health Beliefs Model showed that youth played a greater role in risky behaviors and believes rather than inexperience (Rutter \& Quine, 1996).

Besides this age effect, sex differences are well known in risk-taking. Studies showed that male drivers have more injury and fatal crashes, commit more offences (Laapotti, Keskinen, Hatakka, \& Katila, 2001; ONISR, 2016) and take more risks than females ones (Barjonet, 1990; Cestac \& Delhomme, 2012; Lawton, Parker, Stradling, \& Manstead, 1997; Özkan \& Lajunen, 2005; Pravossoudovitch, Martha, Cury, \& Granié, 2015). Males also tend to 
overestimate their driving skills (Boccara, Delhomme, Vidal-Gomel, Dommès, \& Rogalski, 2010) and evaluate their own driving skills more positively than females do (Delhomme \& Meyer, 2004; Katila, Keskinen, Hatakka, \& Laapotti, 2004). Males’ driving skill assessment is negatively correlated to their risk (Matthews \& Moran, 1986) and to their tendency « to drive over the speed limits » (Parker et al., 1995; Reason, Manstead, Stradling, Baxter, \& Campbell, 1990). Therefore, males tend to evaluate positively their own driving skills, which make them taking more risks while driving, and, thus, having more crashes. Furthermore, males declare taking more risk and committing more offences, while females declare less traffic rules violations (Aberg \& Rimmö, 1998; Byrnes, Miller, \& Schafer, 1999; Lawton et al., 1997; Özkan \& Lajunen, 2005, 2006; Reason et al., 1990; Simon \& Corbett, 1996) and being more respectful of the traffic rules (Guého, 2015; Tom \& Granié, 2011). Researchers showed that males tend to take more risk by deliberately breaking the traffic rules (Byrnes et al., 1999; Lawton et al., 1997; Reason et al., 1990; Simon \& Corbett, 1996).

However, some studies showed that gender (Bem, 1974; Fontayne, Sarrazin, \& Famose, 2000; Gana, 1995) would be a better predictor of risk-taking behavior than sex (Granié, 2009, 2010; Raithel, 2003). Sex and gender have to be distinguished. Sex refers to the biological aspect of the individual (male vs female), whereas gender can be defined as "the characteristics and traits socially and culturally considered as appropriated to males and females" (Unger, 1979), it represents the psychological and social aspect of the individual's sex (masculinity and femininity) (Hurtig, Kail, \& Rouch, 2002; Hurtig \& Pichevin, 1986; Unger, Hurtig, \& Pichevin, 1986). Studies showed that high masculinity, which is strong conformity to masculine social stereotypes, is linked to higher risk-taking in many activities, such as playing sport (Cazenave, Le Scanff, \& Woodman, 2003) or car driving (Guého, Granié, \& Abric, 2012a; Özkan \& Lajunen, 2006; Schmid Mast, Sieverding, Esslen, Graber, \& Jäncke, 2008). Furthermore, driving is an activity which skills are associated to males (Berger, 1986; Degraeve, Granié, Pravossoudovitch, \& Lo Monaco, 2015; Granié \& Pappafava, 2011; Pravossoudovitch et al., 2015). The driving perceptual-motor skills are stereotypically associated with males and this activity is considered as consistent with the masculine social role (Chateignier, Chekroun, Nugier, \& Dutrévis, 2011; Degraeve et al., 2015; Félonneau \& Becker, 2011; Granié \& Pappafava, 2011; Pravossoudovitch, 2016; Sümer, Özkan, \& Lajunen, 2006). The road safety skills are stereotypically associated with females (Degraeve et al., 2015; Granié \& Pappafava, 2011; Pravossoudovitch, 2016; Sümer et al., 2006). Furthermore, these stereotypes affect the individuals' behaviors. Regardless of the individual's sex, the more he/she adheres to the gender stereotypes associated with driving for 
one of the two sex groups, the more he/she declares demonstrating the typical driving behaviors of this sex (Pravossoudovitch, 2016). This relation was also observed with pedestrians (Granié, 2008, 2009): individuals who have a high conformity to masculine gender stereotypes endorse more risk-taking and violations than those who have a high conformity to feminine gender stereotypes. To our knowledge, it has not hitherto been studied among motorcyclists, whereas we know that motorcycling is a mode of transportation essentially used by males, with a very specific crash risk (FFSA \& GEMA, 2012; ONISR, 2016; Oudin, 2009). Thus, we can make the hypothesis that demographic variables (such as sex and age) and psychosocial variables (such as gender) affect risky riding behavior.

A differentiation of risky behaviors should be made between violations - intentional - and mistakes - unintentional - that have different psychological sources and therefore involve different means of prevention and education (Reason et al., 1990). Thus, transgressions involve motivational determinants and imply changing psychological attitudes, whereas mistakes involve cognitive failures and specific training could be used. On a second level, among mistakes, errors must be differentiated from lapses, where lapses (slips and inattention) are involuntary deviations in the action, whereas errors concern failures in intent (Reason et al., 1990). This distinction between violations, errors and lapses has been examined in several studies on drivers using the Driver Behavior Questionnaire (Reason et al., 1990).

Tools derived from the Driver Behavior Questionnaire (DBQ) (Reason et al., 1990) have been developed to specifically measure riders' declared behaviors. One of the most complete questionnaires on riders' behaviors based on the conceptual framework of the DBQ is the Motorcycle Rider Behaviour Questionnaire (MRBQ) used for PTW riders and developed in United Kingdom by Elliott and colleagues (Elliott, Baughan, \& Sexton, 2007). This tool was also validated in Turkey (Özkan, Lajunen, Doğruyol, Yıldırım, \& Çoymak, 2012), in Brazil (Coelho et al., 2012), used in France (Banet, 2010), and was adapted to the Iranian riders (Motevalian, Asadi-Lari, Rahimi, \& Eftekhar, 2011) and the Australian riders (Sakashita, Senserrick, Lo, Boufous, \& de Rome, 2014; Stephens et al., 2017).

Thus, in motorcycle riding as in sports, different types of practices and motives associated can be differentiated. Riding a motorcycle can be linked to sport, with a strong physical involvement and shared motivations. These types of practice are more or less dangerous, and motives can be used as a marker of commitment to action. Based on the sensation seeking concept developed by Zuckerman (Zuckerman, 1979, 1994), which stated a link between sensation seeking and risk taking, Recours and colleagues (Recours, Souville, \& Griffet, 
2004) differentiated four motives to sport practice. Competition is the accomplishment derived from feeling stronger than others, where individuals participate to the activity to prove themselves (Duda, 1995; Recours et al., 2004). Exhibitionism is showing ones superiority to others, where individuals want to be seen and to impress others (Recours et al., 2004). Sociability is the will to share and to interact with others (Griffet, 1994; Recours et al., 2004). Playing to the limits is going as far as the individual can, until feeling conflicting sensation between scare and safety (Recours et al., 2004). Note that Tunnicliff et al. (Tunnicliff et al., 2012) use the concept of pushing the limits, defined as one of the three riskiest riding behaviors that can lead to a crash. However, the definition of these behaviors proposed by Recours et al. (2004) was more detailed and accurate and was used in this study. This study showed that motives in sport practices differed according to individuals' sex: males declared more motives related to competition and exhibitionism, whereas females frequently declared motives related to sociability (Recours et al., 2004). Furthermore, one study on the relationship between sporting practices and risky driving shown that male highrisk sport practitioners (e.g. BASE jumpers or paragliders) have more risky behaviors and traffic crashes as drivers than those who practice low-risk sports (e.g. swimming or dancing) (Martha, Laurendeau, \& Griffet, 2010). According to the authors, this specific population of sportsmen developed a high self-confidence due to their sporting practices, which leads them to take more risks in their daily activities, such as driving a car.

Some previous studies (Bem, 1981; Kelling, Zirkes, \& Myerowitz, 1976) also showed that conformity to masculine stereotypes made individuals more prone to declare risk-taking and being confident, whereas concern for others was a feminine behavior. Although, other studies showed similar links among car drivers and pedestrians (Granié, 2008; Pravossoudovitch, 2016) where risk-taking was closely related to masculinity. To our knowledge, no study has yet explored the relationship between gender stereotype conformity, motives and riders' behaviors.

The objective of the present study is to analyze the effects of the conformity to masculine and feminine stereotypes and of the different motives to ride on the riders' risk-taking behaviors. Based on the scientific literature, we expect high conformity to masculine stereotype and motives linked to competition and playing with the limits to be linked to higher risk taking behaviors. Furthermore, as the literature showed, motives linked to competition and exhibitionism, were more frequent among males (Recours et al., 2004). It was also showed that masculinity was linked to risk taking (Cazenave et al., 2003; Guého, Granié, \& Abric, 2012b; Özkan \& Lajunen, 2006; Schmid Mast et al., 2008). We expect to identify a link 
between sex, gender stereotype conformity and motives, but also between motives and aberrant behaviors on our riders' population. More specifically, we expect to find that motives, like competition and exhibitionism, would be a mediator in the relationship between masculinity and risk-taking while riding, in this population where males are over-represented (FFSA \& GEMA, 2012; Oudin, 2009).

\section{Method}

\section{Materials}

Motorcyclists were recruited through social networks and web forums and were invited to respond to an anonymous online 20 minutes questionnaire entitled "Powered two-wheelers and sport practices". This questionnaire was presented as a research on PTW riders, with no more information, except that the results would be completely anonymous and that we needed to have the most truthful answer, knowing that there was no good or no bad answer.

The first part of the questionnaire was devoted to demographic questions (sex, age, socioeconomic status) and motorcycle usage (license age, motorcycle category, annual average mileage and crash number of the last 12 months).

The second part is devoted to the Motorcycle Rider Behavior Questionnaire (MRBQ), to the motives for riding a motorcycle and to the Bem Sex-Role Inventory (BSRI) (Bem, 1974; Fontayne et al., 2000; Pfeffer, Fagbemi, \& Stennet, 2010).

To measure riders' aberrant behaviors, the present study used the French version of the Motorcycle Rider Behaviour Questionnaire (Coquelet, Granié, \& Griffet, Submitted). This version was developed for the French riders' population, and was based on the original British Motorcycle Rider Behaviour Questionnaire (Elliott et al., 2007) and the French version of the Driver Behavior Questionnaire (Guého et al., 2014).

On a six-point Likert scale (from 'never' to 'almost always'), the MRBQ was developed to determine motorcyclists' risky declared behaviors. The scale is made of 25 items, differentiating five dimensions: aggressive violations (five items, e.g. 'You get angry with a certain type of driver and show him your hostility by any available means'); lapses (eight items, e.g. 'Distracted or pre-occupied, you belatedly realize that the vehicle in front has slowed and you have to brake hard to avoid a collision'); personal protective equipment (PPE) negligence (three items, e.g. 'You ride short distances without fastening your helmet'); deliberate risk-taking (four items, e.g. 'You intentionally do a "wheelie".'); ordinary violations (five items, e.g. 'You straddle lane to overtake the vehicles in front of you'). 
215 Cronbach's alphas are acceptable (aggressive violations, $\alpha=0.70$; lapses, $\alpha=0.73$; deliberate risk-taking, $\alpha=0.71$; ordinary violations, $\alpha=0.71)$, except for PPE negligence $(\alpha=0.49)$. Despite the low PPE negligence Cronbach's alpha, we decided to keep this factor to stay as close as possible to the previous MRBQ versions, included this version of Sakashita and colleagues (Sakashita et al., 2014) which alpha was .47.

Scale on motives for riding a motorcycle was based on a validated scale on sport motivations (Recours et al., 2004). The original scale was composed of 13 items differentiating four dimensions: competition (3 items), exhibitionism (3 items), sociability (3 items) and playing to the limit (4 items). To reduce the questionnaire's time administration and as the objective of the study was to explore the effects of competition, exhibitionism, playing to the limits and sociability on risk-taking while riding, some of the items, related to these dimensions, were selected from the original scale. Thus, the scale was composed of eight items. First, items defined by individual's confrontation to his/her own performance and other performance were selected. Two items were related to playing to the limit, that is self-confrontation ('to take risks', 'situations which give me at the same time a safe and an unsafe feeling'); three items were related to competition, that is competition with others ('to face challenges', 'To ride as fast as possible', 'to race'). Second, items related to two types of relationship with others were selected. Two items were related to exhibitionism ('to be looked at', 'to attract attention by the way I ride'); and one item, was related to sociability ('to share an experience, a moment with others'). Participants were invited to respond on a six-point Likert scale (from 'strongly disagree' to 'strongly agree') to these eight items: 'Here you can find some examples of what can be pleasant for a rider. For each example, tell us what you like or would like to do as a rider.'

To measure riders' conformity to gender stereotypes, the BSRI (Bem, 1974) was used, in its short French version validated by Fontayne et al. (Fontayne et al., 2000). This version consisted of 18 items. Ten items (e.g. I care for others') measured 'Femininity' and eight items measured 'masculinity' (e.g. 'I am dominant'). The riders were invited to respond on a seven-point Likert scale (from 'never true' to 'always true'): 'In the following proposals, tell what is the most notable in your character.' The reliability of these two factors (masculinity and femininity) was good (Cronbach's alphas: masculinity, $\alpha=0.812$; femininity, $\alpha=0.879$ ). 


\section{Participants}

This self-reported questionnaire was distributed through social networks, motorcyclists' web forums and websites, and via a targeted email campaign. The Internet is an effective medium for the posting, exchange, and collection of information in psychology and sociology-related research and data. Moreover, this way of administration is easier, less expensive than and as reliable as the more traditional paper-and-pencil way (Gosling, Vazire, Srivastava, \& John, 2004; Riva, Teruzzi, \& Anolli, 2003).

Only people who rode a PTW vehicle on open roads were invited to participate to this survey (individuals who only drive on racetracks or off-road were eliminated). The participants then comprised 2,500 riders from all over France, with 1\% moped riders, 7.7\% light motorcycle riders (motorcycles under $125 \mathrm{cc}$, that can be ride with a simple two-year-old car license) and $90.5 \%$ heavy motorcycles (HM, motorcycles over $125 \mathrm{cc}$ ). To avoid any bias in our results with such an imbalance between these three groups, it was decided to work exclusively on the HM rider sample. It should be noted that in France only adults over 18 years old, with a specific driving license (the A license) are allowed to ride HM.

The distribution by sex was consistent with the distribution of the French motorcyclist population: $10.5 \%$ of the sample was women whereas $12 \%$ of the 'active' riders of HM (as a driver and not as a passenger) in France in 2010 were women (ONISR, 2011).

Ages ranged from 18 to 78 years: $45.8 \%$ were aged 30-49. The mean age was 37 years (Male: $M=37.03$, $S D=12.19$; Female: $M=36.35, S D=10.98$ ). As presented in Table 1, the participants were separated into five age groups. The distribution by age was close for the two sexes $\left(K h i 2_{(\mathrm{ddl}=4)}=2.49, n s\right)$. The youngest (18-25) were divided in two sub-groups (18-20 and 2124) to see if potential aberrant behaviors of the very young riders can be distinguished from the others.

Table 1. Numbers by sex for each age group

\begin{tabular}{lllllll}
\hline Sex & \multicolumn{9}{l}{ Age group (years) } & Total \\
\cline { 2 - 6 } & $18-20$ & $21-24$ & $25-29$ & $30-49$ & $50-80$ & \\
\hline Male & 88 & 293 & 334 & 926 & 384 & 2025 \\
Female & 9 & 29 & 47 & 110 & 42 & 237 \\
Total & 97 & 322 & 381 & 1036 & 426 & 2262 \\
\hline
\end{tabular}




\section{Results}

Motives for riding a motorcycle

First, to use motives as independent variables, a principal component analysis with direct Oblimin rotation was carried out on all eight items of the riding motive scale. The scree plot indicated a two-factor solution, which accounted for $64.08 \%$ of the total variance. Table 2 shows the means, standard deviations and loadings on each axis for each item of the twofactor solution. An item loaded $>0.39$ on both factorial axes was excluded ("to draw our attention by the way I ride").

Table 2. Means and standard deviations for the eight motives items and the two-factor solution (direct oblimin rotation)

\begin{tabular}{llll}
\hline Items (number) & Mean (SD) & 1 & 2 \\
\hline To race & $1.93(1.255)$ & .863 & \\
To face challenges & $1.92(1.272)$ & .844 & \\
To ride as fast as possible & $2.27(1.274)$ & .813 & \\
To take risks & $2.02(1.137)$ & .802 & \\
Situations which give me at the same & $2.20(1.284)$ & .760 & \\
time a safe and an unsafe feeling & $3.08(1.570)$ & & .847 \\
To be looked at & $4.74(1.422)$ & & .763 \\
To share an experience, a moment with & & \\
others & & & \\
\hline
\end{tabular}

The first axis, competition motives, explained $51.94 \%$ of the variance. It was defined by five items related to competition and to playing to the limit. All these items had in common the idea of competition (self-competition or competition with others).

The second axis, social motives, explained $14.46 \%$ of the variance and was determined by two items: an item related to exhibitionism and an item related to sociability. These two items were defined by the notion of relationship with community, by differentiating oneself from others or by sharing with others.

Whereas the reliability of the competition motives is acceptable $(\alpha=0.875)$, the reliability for social motives was very low $(\alpha=0.463)$ and this dimension was not kept for further analysis.

\section{Relationship between sex, age, gender and motives for riding a motorcycle}

A regression model was developed to predict the effect of sex, age, and conformity to gender stereotypes as independent variables and competition motives for riding a motorcycle as dependent variables (see Table 3). 
Table 3.Standardized regression coefficients and significance levels for competition motives for riding a motorcycle

\begin{tabular}{ll}
\cline { 2 - 2 } & $\begin{array}{c}\text { Competition } \\
\text { motives }\end{array}$ \\
\hline Sex ${ }^{\mathrm{a}}$ & -.036 \\
Age & $-.351^{* * *}$ \\
Femininity & $-.083^{* * *}$ \\
Masculinity & $.226^{* * *}$ \\
Adjusted $R^{2}$ & $.185^{* * *}$ \\
\hline$* p<0.05 \quad{ }^{* *} p<0.01 \quad{ }^{* * *} p<0.001$ \\
${ }^{\mathrm{a}} 1=$ Male, $2=$ Female
\end{tabular}

The model was significant $\left(F_{(4,2019)}=115.64, \mathrm{p}<.001\right)$ for competition motives, explaining $18.5 \%$ of the variance and showed that competition motives for riding a motorcycle were associated with respondent's age and conformity to gender stereotypes. Masculinity was positively associated with the reported competition motives for riding a motorcycle, whereas age and femininity were negatively associated with them.

\section{Relationship between all variables and $M R B Q$ dimensions}

To test our hypothesis, regression analysis were made to determine which variables were predictors of each of the five MRBQ dimensions: aggressive violations, lapses, PPE negligence, deliberate risk-taking and ordinary violations. For each of the five continuous variables (aggressive violations, lapses, PPE negligence, deliberate risk-taking and ordinary violations), a first model was tested, with sex (male vs female), age, femininity and masculinity as predictors. In a second model, the competition motives dimension was added (see Table 4). The aim of this procedure in two steps was to test the mediating role of motives to ride a motorcycle in the relation between gender and aberrant behaviors. The regression procedure advocated by Baron and Kenny (Baron \& Kenny, 1986) was followed. It first requires that the mediating variable (e.g., competition motives) be related to the independent variable (e.g., gender) and the dependent variable (e.g., aberrant behaviors). In addition, the other requirement specified by Baron and Kenny is that a mediating variable should predict the dependent variable (aberrant behaviors) even when the independent variable (gender) is statistically controlled, while the effect of the independent variable on the dependent measure should be substantially reduced when the mediating variable is statistically controlled. To confirm the mediation, Sobel tests ( $z$-score test) were performed (Baron \& Kenny, 1986; “Interactive Mediation Tests," n.d.). 
Table 4. Standardized regression coefficients and significance levels for MRBQ dimensions

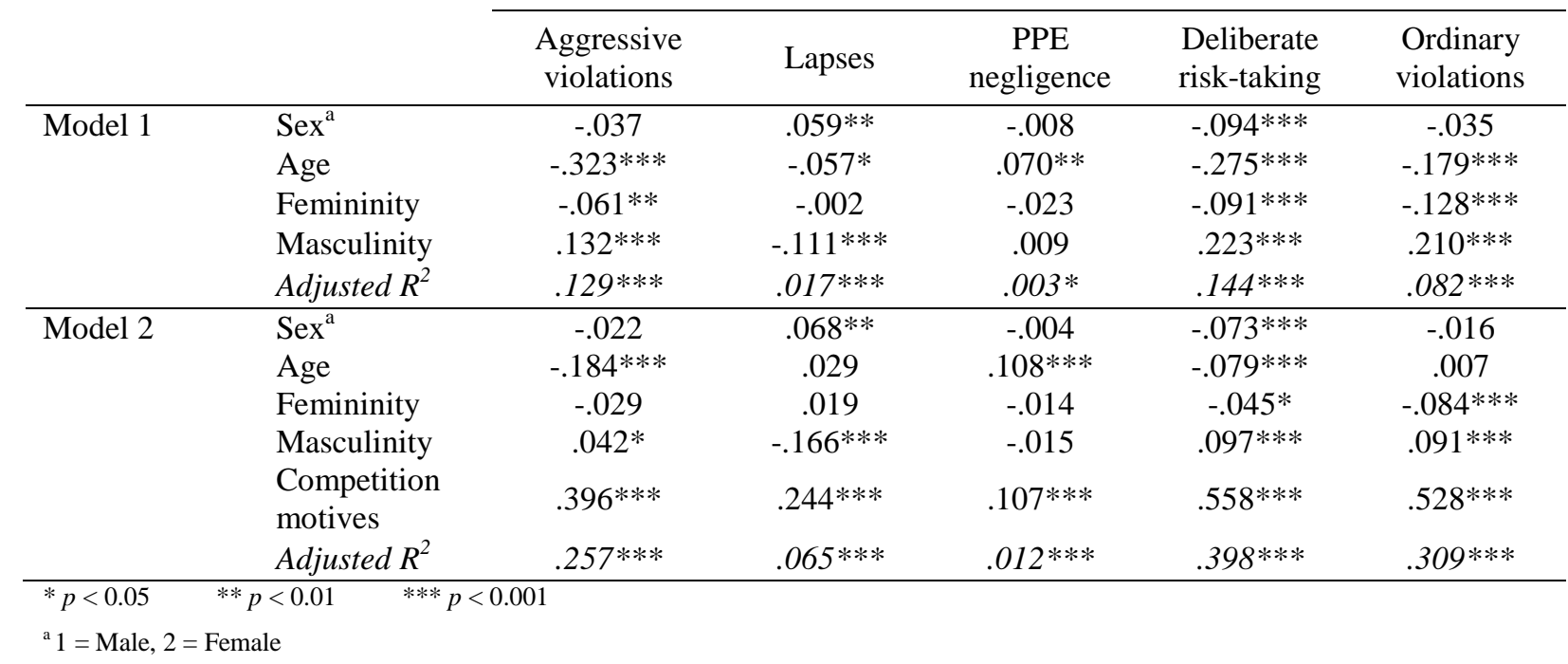

The first model for aggressive violations was significant $\left(F_{(4,2019)}=75.97, \mathrm{p}<.001\right)$. Age and femininity inhibited whereas masculinity reinforced aggressive violations. The second model, with the introduction of competition motives, was also significant $\left(F_{(5,2018)}=140.66, \mathrm{p}<.001\right)$.

340 Femininity $(\beta=-.061, \quad p<.01)$ became non-significant when competition motives was statistically controlled $(\beta=-.029, n s)$, but a simple regression with femininity and competition motives showed that femininity has no effect on competition motives, which means that competition motives was not a mediator between femininity and other variables. Masculinity $(\beta=.132, p<.001)$ became less significant when competition motives was statistically controlled $(\beta=.042, p<.05)$. To test whether this pattern of results reflects a significant reduction in the variance accounted for by masculinity, a $z$-score test (Sobel test) was performed ("Interactive Mediation Tests," n.d.; "Mediation (David A. Kenny)," n.d.). The Sobel test was significant $(z=9.854, p<.001)$ and showed that competition motives mediated the relationship between masculinity and aggressive behaviors, a high masculinity level was positively associated with competition motives to ride a motorcycle which were positively associated with aggressive violations.

The first regression model for lapses was significant $\left(F_{(4,2019)}=9.89, \mathrm{p}<.001\right)$. Femaleness was positively associated, whereas age and masculinity were negatively associated with lapses. The second model was also significant $\left(F_{(5,2018)}=29.27, \mathrm{p}<.001\right)$ and showed that femaleness and competition motives were positively associated, whereas masculinity was negatively associated with lapses. Masculinity $(\beta=-.111, p<.001)$ remained significant when competition motives was statistically controlled $(\beta=-.166, p<.001)$ but the Beta decreased. The Sobel test was significant $(z=7.411, p<.001)$ and showed that competition motives mediated the 
relationship between masculinity and lapses. A high masculinity level was positively associated with competition motives to ride a motorcycle, which was positively associated with lapses.

The first model for PPE negligence was significant $\left(F_{(4,2019)}=2.73, \mathrm{p}<.05\right)$ and showed that age reinforced PPE negligence. The second model was also significant $\left(F_{(5,2018)}=6.00, \mathrm{p}<.001\right)$ and showed that PPE negligence was positively associated with age and competition motives for riding a motorcycle.

The first model concerning deliberate risk-taking was significant $\left(F_{(4,2019)}=86.32, \mathrm{p}<.001\right)$ and showed that femaleness, age and femininity were negatively associated whereas masculinity was positively associated with risk-taking behaviors. The second model was also significant $\left(F_{(5,2018)}=268.77, \mathrm{p}<.001\right)$ and showed that competition motives for riding a motorcycle was also positively associated with risk-taking behaviors. Masculinity $(\beta=.223, p<.001)$ remained significant when competition motives was statistically controlled $(\beta=.097, p<.001)$ but the Beta decreased. The Sobel test was significant $(z=10.27, p<.001)$ and showed that competition motives mediated the relationship between masculinity and deliberate risk-taking. A high masculinity level was positively associated with competition motives to ride a motorcycle, which was positively associated with deliberate risk-taking.

The first model for ordinary violations was significant $\left(F_{(4,2019)}=46.38, \mathrm{p}<.001\right)$ and showed that femaleness and femininity were negatively associated whereas masculinity was positively associated with ordinary violations. The second model was also significant $\left(F_{(5,2018)}=181.95\right.$, $\mathrm{p}<.001)$ and showed that competition motives for riding a motorcycle was also positively associated with ordinary violations. Masculinity $(\beta=.210, p<.001)$ kept significant when competition motives was statistically controlled $(\beta=.091, p<.001)$ but the Beta decreased. The Sobel test was significant $(z=10.051, p<.001)$ and showed that competition motives mediated the relationship between masculinity and ordinary violations, which means that a high masculinity level was positively associated with competition motives to ride a motorcycle which was positively associated with ordinary violations.

\section{DISCUSSION}

The aim of this study was to analyze the effects of the conformity to masculine and feminine stereotypes, of the different motives to ride on the riders' risk-taking behaviors and to explore 
the mediated relationship between masculinity and risk-taking by the competition motives to ride a motorcycle.

According to our results, sex and gender were predictors of MRBQ dimensions: Femaleness and low masculinity were associated with lapses, while maleness, low femininity and high masculinity were associated with violations. These results are in line with other studies that showed a greater propensity among females to declare more errors and males to declare more road transgressions (Aberg \& Rimmö, 1998; Özkan, Lajunen, \& Summala, 2006; Pravossoudovitch, 2016). This could be explained by gender stereotype conformity: the present study showed that masculinity was positively associated with ordinary violations and deliberate risk taking, and negatively associated with lapses. Femininity was negatively associated with aggressive and ordinary violations. Previous studies (Bem, 1981; Granié, 2013; Kelling et al., 1976) showed that in western societies, masculinity is stereotypically associated with risk-taking. Risk-taking has a greater social value for males than for females (Hopkins \& Emler, 1990), and this is probably why male riders declared more violations, mainly in a masculine and coded sub-group such as that of motorcycle riders (Berger, 2007; Favre, 1980; Oudin, 2009).

It was shown that age was associated with PPE negligence (for the oldest participants), deliberate risk-taking and aggressive violations (for the youngest participants). In the literature on riders as well as on drivers (Aberg \& Rimmö, 1998; Özkan \& Lajunen, 2005; Özkan et al., 2006; Rutter \& Quine, 1996), it was found that the youngest declare more violations than the oldest, in particular for young males.

The results showed that competition motives were associated with gender and age: masculinity was positively associated with competition motives, whereas femininity and age were negatively associated with competition motives. Youth, high masculinity and low femininity were associated with of competition motives. Recours et al. (2004) observed that, in sport practice, females were more likely to be motivated by sociability, whereas males were more attracted by competition and exhibitionism. As previously shown in the literature (Bem, 1974; Fontayne et al., 2000), the results of the present study show that males and more generally individuals complying with masculine gender stereotypes are more motivated by self-confidence and competition, which are conducive to more risk-taking.

The present study showed that our new scale for motives for riding a motorcycle, based on a sport practicing study, was effective. It allowed to highlight two major dimensions (competition motives and social motives) and to gain new information on the reasons why 
riders have chosen to ride a motorcycle and how these motives could affect the way the riders behave on HM.

As Recours et al. (2004, p.2) stated, for sport practices, "motive is an interaction of internal factors (unconscious and conscious psychological compulsions) and external factors (social and familial gratification and recognition)." Here, for motorcycle practice, competition motives can be associated with 'internal factors' and social motives with 'external factors', as the first involve an action to test and surpass oneself; the second are related to social recognition and significance, by differentiating oneself or sharing an experience. Results hence showed that competition motives were positively associated with all the MRBQ dimensions. The more the riders declared competition motives to ride a motorcycle, the more they declared aberrant behaviors. It was also shown that motives were mediators between gender and all the aberrant behaviors, except PPE negligence. It seems that riding for competition motives, which are highly associated with masculinity as our results showed, played a masculinity booster role, which means that people who have a high level of masculinity tended to declare aberrant behaviors, and that this phenomenon is reinforced if they also declared competition motives to ride a motorcycle. Thus, level of masculinity leads participants to be more motivated by playing to the limit, competition and challenge that bring them to declare more frequently aberrant behaviors.

Some limitations should be taken into account. Some studies showed that declared behaviors collected with the DBQ or tools developed from the DBQ are very close to the real road users' behaviors. First, the responses to the DBQ seem not to be affected by the social desirability (Lajunen \& Summala, 2003; Sullman \& Taylor, 2010). Then, other studies showed that some behaviors highlighted by the DBQ were valid measures of actual behaviors (Zhao et al., 2012; Helman \& Reed, 2015). Thus, even if we cannot guarantee that the aberrant behaviors highlighted by the present study are the effective riders' behaviors, we can suppose they are close to their real way to ride.

450 Moreover, the individuals targeted are riders who are often passionate about motorcycles. According to Crosset \& Beal (1997), individuals who belong to a sub-world, like that of heavy motorcycles, are passionate and readily take part in a questionnaire designed for them. Moreover, the participants were essentially recruited through social media (specialized pages on social networks and web forums), which means that this population can be considered motorcycle 'specialists.' This could have skewed our results, since our sample may not be representative of the entire French rider population. New studies should be conducted on the more general population of riders (especially one that does not only use PTW) and on car 
drivers, allowing comparing the results on these two road users' populations. However, this study already gives new knowledge concerning the riders of HM, especially on the link between aberrant riding behaviors and sex, gender, motives for riding. 


\section{Appendix}

MRBQ's five dimensions and 25 items

\begin{tabular}{|c|c|}
\hline Dimensions & Items \\
\hline \multirow{5}{*}{$\begin{array}{l}\text { Aggressive } \\
\text { violations }\end{array}$} & $\begin{array}{l}\text { You sound the horn, roar your engine, or flash your headlight to show your irritation to another } \\
\text { driver }\end{array}$ \\
\hline & $\begin{array}{l}\text { You can't overtake the vehicle in front of you, whose speed is too slow according to you, and you } \\
\text { make the driver understand by gesturing at him }\end{array}$ \\
\hline & You get angry with a certain type of driver and show him your hostility by any available means \\
\hline & A driver bothers you. You overtake and cut him up \\
\hline & You 'stick' to the vehicle ahead of you \\
\hline \multirow{9}{*}{ Lapses } & You notice belatedly the flashing green arrow authorizing you to turn \\
\hline & You notice belatedly the light has turned green \\
\hline & Distracted or pre-occupied, you belatedly realize that the vehicle in front has slowed and you \\
\hline & have to brake hard to avoid a collision \\
\hline & You lose your balance and nearly fall while you're stopped \\
\hline & You stall when stopping or getting going again \\
\hline & You enter a bend too fast and feel as if you might lose control \\
\hline & $\begin{array}{l}\text { You mean to ride to destination } \mathrm{A} \text {, and you 'wake up' on the road to destination B, maybe } \\
\text { because you are accustomed to going there }\end{array}$ \\
\hline & You forget to raise the stand before selecting first gear \\
\hline \multirow{3}{*}{$\begin{array}{l}\text { PPE } \\
\text { negligence }\end{array}$} & You decide not to wear gloves \\
\hline & You ride short distances without fastening your helmet \\
\hline & You ride without wearing specific motorcycle protective clothes \\
\hline \multirow{4}{*}{$\begin{array}{l}\text { Deliberate } \\
\text { risk-taking }\end{array}$} & You intentionally do a 'wheelie' \\
\hline & You intentionally brake hard to do a 'stoppie' \\
\hline & You intentionally do a wheel spin \\
\hline & You get involved in unofficial races with other riders or drivers \\
\hline \multirow{5}{*}{$\begin{array}{l}\text { Ordinary } \\
\text { violations }\end{array}$} & You straddle lanes to overtake the vehicles in front of you \\
\hline & You disregard the speed limit late in the evening, at night or in the early hours of the morning \\
\hline & You open up the throttle and just 'go for it' on country roads \\
\hline & $\begin{array}{l}\text { You ride on the zebra areas or on the emergency lanes to jump ahead of vehicles which are } \\
\text { stopped or driving slowly }\end{array}$ \\
\hline & You ride between two lanes of fast moving traffic \\
\hline
\end{tabular}




\section{References}

Aberg, L., \& Rimmö, P.-A. (1998). Dimensions of aberrant driver behaviour. Ergonomics, 41(1), 3956. https://doi.org/10.1080/001401398187314

Banet, A. (2010). Conscience du risque et attitudes face aux risques chez les motocyclistes (Psychologie). Lumière Lyon 2, Lyon.

Barjonet, P. E. (1990). Appartenances socioculturelles, styles de vie et participation à la sécurité, Actes du symposium international. Le Comportement Des Conducteurs Dans Un Contexte Social, 163-171.

Baron, R. M., \& Kenny, D. A. (1986). The moderator-mediator variable distinction in social psychological research: Conceptual, strategic, and statistical considerations. Journal of Personality and Social Psychology, 51(6), 1173.

Bem, S. L. (1974). The measurement of psychological androgyny. Journal of Consulting and Clinical Psychology, 42(2), 155-162.

Bem, S. L. (1981). Gender schema theory: A cognitive account of sex typing. Psychological Review, 88(4), 354.

Berger, D. (2007). Motards à l'âge adulte. Normes et pratiques d'un groupe déviant (Mémoire de Master 1 - Sociologie). Paris 8, Paris.

Berger, M. L. (1986). Women drivers! The emergence of folklore and stereotypic opinions concerning feminine automotive behavior. Women's Studies International Forum, 9(3), 257-263. https://doi.org/10.1016/0277-5395(86)90061-0

Boccara, V., Delhomme, P., Vidal-Gomel, C., Dommès, A., \& Rogalski, J. (2010). Seniors' perceived driving skill in a postlicense training program: comparison of instructors' assessments and self-assessments by seniors' age and sex. Perceptual and Motor Skills, 110(1), 117-128.

Byrnes, J. P., Miller, D. C., \& Schafer, W. D. (1999). Gender differences in risk taking: A metaanalysis. Psychological Bulletin, 125(3), 367-383. https://doi.org/10.1037/00332909.125.3.367

Cazenave, N., Le Scanff, C., \& Woodman, T. (2003). Influence du sexe sur les profils fuite et compensation dans la prise de risque.

Cestac, J., \& Delhomme, P. (2012). European road users' risk perception and mobility, The SARTRE 4 survey. IFSTTAR. 
Chateignier, C., Chekroun, P., Nugier, A., \& Dutrévis, M. (2011). «Femme au volant...» : effet de la menace du stéréotype et de la colère sur les performances des femmes à une tâche liée à la conduite automobile. Année Psychologique, 111(4), 673.

Coelho, R. P. S., Grassi-Oliveira, R., Machado, M., Williams, A. V., Matte, B. C., Pechansky, F., ... Szobot, C. M. (2012). Translation and adaptation of the Motorcycle Rider Behavior Questionnaire: a Brazilian version. Cadernos de Saúde Pública, 28(6), 1205-1210. https://doi.org/10.1590/S0102-311X2012000600019

Coquelet, C., Granié, M.-A., \& Griffet, J. (Submitted). Effect of sex, age, accidents on riders' behaviors. Accident Analysis \& Prevention.

Coquelet, C., Granié, M.-A., \& Griffet, J. (2014). Les femmes en deux-roues motorisés: Evolution de l'accidentalité. Poster presentation presented at the 10ème Journée de l'Ecole Doctorale Sciences du Mouvement Humain, Montpellier.

Crosset, T., \& Beal, B. (1997). The use of "Subculture" and "Subworld" in ethnographic works on sport: a discussion of definitional distinctions. Sociology of Sport Journal, (14), 73-85.

de Winter, J. C. F., \& Dodou, D. (2010). The Driver Behaviour Questionnaire as a predictor of accidents: A meta-analysis. Journal of Safety Research, 41(6), 463-470. https://doi.org/10.1016/j.jsr.2010.10.007

Degraeve, B., Granié, M.-A., Pravossoudovitch, K., \& Lo Monaco, G. (2015). Social representations associated with men and women drivers among French adolescents and adults. Effects of perceiver's age, sex, and socioeconomic status. Transportation Research Part F: Traffic Psychology and Behaviour.

Delhomme, P., \& Meyer, T. (2004). Risk taking and self-efficacy among young male drivers: Selfefficacy and changing task demands. Traffic and Transport Psychology: Theory and Application, 135-146.

Duda, J. L. (1995). Motivation in sport settings: A goal perspective approach. In Motivation in sport and exercise (pp. 57-91). Champaign, IL, US: Human Kinetics Books.

Elliott, M. A., Baughan, C. J., \& Sexton, B. F. (2007). Errors and violations in relation to motorcyclists' crash risk. Accident Analysis \& Prevention, 39(3), 491-499.

Favre, C. (1980). Les motards. Le "phénomène moto", les jeunes et leur vie communautaire (Privat). Toulouse. 
Félonneau, M.-L., \& Becker, M. (2011). «Femmes au volant, danger au tournant» Les conductrices sont-elles victimes d'une menace de stéréotype? Psychologie Du Travail et Des Organisations, 17(4), 314-329.

FFSA, \& GEMA. (2012). Etude sur les deux-roues en France (Etudes et Statistiques). Paris.

Fontayne, P., Sarrazin, P., \& Famose, J.-P. (2000). The Bem Sex-Role Inventory: Validation of a Short Version for French Teenagers. European Review of Applied Psychology, 50(4), 405-416.

Gana, K. (1995). Androgynie psychologique et valeurs socio-cognitives des dimensions du concept de soi. Les Cahiers Internationaux de Psychologie Sociale, (25), 27-43.

Gosling, S. D., Vazire, S., Srivastava, S., \& John, O. P. (2004). Should we trust web-based studies? A comparative analysis of six preconceptions about Internet questionnaires. American Psychologist, 59(2), 93-104. https://doi.org/10.1037/0003-066X.59.2.93

Granié, M.-A. (2008). Influence de l'adhésion aux stéréotypes de sexe sur la perception des comportements piétons chez l'adulte. In Recherche, transports, sécurité (pp. 253-263). Lavoisier. Retrieved from http://cat.inist.fr/?aModele=afficheN\&cpsidt=21234151

Granié, M.-A. (2009). Effects of gender, sex-stereotype conformity, age and internalization on risktaking among adolescent pedestrians. Safety Science, 47(9), 1277-1283.

545 Granié, M.-A. (2013). Genre et rapport au risque : de la compréhension au levier pour l'action. Questions Vives. Recherches en éducation, 9(19), 65-87. https://doi.org/10.4000/questionsvives.1273

Granié, M.-A., \& Pappafava, E. (2011). Gender stereotypes associated with vehicle driving among French preadolescents and adolescents. Transportation Research Part F: Traffic Psychology and Behaviour, 14(5), 341-353.

Griffet, J. (1994). Décision, risque, émotion. Science et Motricité, 23, 3-12.

Guého, L. (2015). Approche psychosociale des effets de l'identité sexuée sur les comportements à risque déclarés au volant et dans différents domaines chez les jeunes conducteurs. Aix Marseille Université, Aix en Provence.

555 Guého, L., Granié, M.-A., \& Abric, J.-C. (2012a). Effet de l'âge, du sexe et de l'identité de genre sur les comportements à risque routiers (pp. 152-154). Presented at the 54ème Congrès de la Société Française de Psychologie, Montpellier: Université Montpellier 3. 
Guého, L., Granié, M.-A., \& Abric, J.-C. (2012b). Effet de l'âge, du sexe et de l'identité de genre sur les comportements à risque routiers. Actes Du 54ème Congrès de La Société Française de Psychologie, 124, 152.

Guého, L., Granié, M.-A., \& Abric, J.-C. (2014). French validation of a new version of the Driver Behavior Questionnaire (DBQ) for drivers of all ages and level of experiences. Accident Analysis \& Prevention, (63), 41-48.

Helman, S., Reed, N. (2015). Validation of the driver behavior questionnaire using behavioural data from an instrumented vehicle and high-fidelity driving simulator. Accident Analysis \& Prevention, (75), 245-251. http://dx.doi.org/10.1016/j.aap.2014.12.008

Hopkins, N., \& Emler, N. (1990). Social Network Participation. Health Hazards in Adolescence, (8), 385.

Hurtig, M. C., Kail, M., \& Rouch, H. (2002). Sexe et genre. De la hiérarchie entre les sexes [Sex and Gender. On hierarchy between genders]. Paris: CNRS.

Hurtig, M. C., \& Pichevin, M. F. (1986). La différence des sexes: questions de psychologie. 'Editions Tierce.

Interactive Mediation Tests. (n.d.). Retrieved May 22, 2017, from http://www.quantpsy.org/sobel/sobel.htm

575 Katila, A., Keskinen, E., Hatakka, M., \& Laapotti, S. (2004). Does increased confidence among novice drivers imply a decrease in safety? The effects of skid training on slippery road accidents. Accident Analysis \& Prevention, 36(4), 543-550. https://doi.org/10.1016/S00014575(03)00060-5

Kelling, G. W., Zirkes, R., \& Myerowitz, D. (1976). Risk as Value: A Switch of Set Hypothesis. Psychological Reports, 38(2), 655-658. https://doi.org/10.2466/pr0.1976.38.2.655

Laapotti, S., Keskinen, E., Hatakka, M., \& Katila, A. (2001). Novice drivers' accidents and violations - a failure on higher or lower hierarchical levels of driving behaviour. Accident Analysis \& Prevention, 33(6), 759-769. https://doi.org/10.1016/S0001-4575(00)00090-7

Lajunen, T., Summala, H. (2003). Can we trust self-reports of driving? Effects of impression management on driver behaviour questionnaire responses. Transportation Research Part F: Traffic Psychology and Behaviour, 6, 97-107. https://doi.org/10.1016/S1369-8478(03)00008-1 
Lassarre, S., Coquelet, C., Hoyau, P., \& Lahatte, A. (2008). Impact de l'attrition d'un panel de jeunes conducteurs sur l'analyse du risque. Méthodes de Sondage: Applications Aux Enquêtes Longitudinales, à La Santé, Aux Enquêtes Électorales..., 72.

Lawton, R., Parker, D., Stradling, S. G., \& Manstead, A. S. (1997). Predicting road traffic accidents: The role of social deviance and violations. British Journal of Psychology, 88(2), 249-262.

Martha, C., Laurendeau, J., \& Griffet, J. (2010). Comparative optimism and risky road traffic behaviors among high-risk sports practitioners. Journal of Risk Research, 13(4), 429-444. https://doi.org/10.1080/13669870903169275

Matthews, M. L., \& Moran, A. R. (1986). Age differences in male drivers' perception of accident risk: The role of perceived driving ability. Accident Analysis \& Prevention, 18(4), 299-313. https://doi.org/10.1016/0001-4575(86)90044-8

Mediation (David A. Kenny). (n.d.). Retrieved May 29, 2017, from http://davidakenny.net/cm/mediate.htm

Motevalian, S. A., Asadi-Lari, M., Rahimi, H., \& Eftekhar, M. (2011). Validation of a Persian Version of Motorcycle Rider Behavior Questionnaire. Annals of Advances in Automotive Medicine / Annual Scientific Conference, 55, 91-98.

Obriot-Claudel, F., \& Gabaude, C. (2004). The Driver Behaviour Questionnaire: A French study applied to elderly drivers. Proceedings of the ICTTP. Retrieved from http://www.researchgate.net/profile/Catherine_Gabaude/publication/237501805_The_Driver_ Behaviour_Questionnaire_A_French_study_applied_to_elderly_drivers/links/0ł31753c6a10dc a263000000.pdf

ONISR. (2001). Accidents corporels de la circulation routière année 2000 (La Documentation Française). Paris.

ONISR. (2011). La sécurité routière en France. Bilan de l'accidentalité de l'année 2010 (La Documentation Française). Paris.

ONISR. (2015). La sécurité routière en France. Bilan de l'accidentalité de l'année 2013 (La Documentation Française). Paris.

ONISR. (2016). La sécurité routière en France. Bilan de l'accidentalité de l'année 2015 (La Documentation Française). Paris. 
ONISR. (2017). La sécurité routière en France. Bilan de l'accidentalité de l'année 2016 (La Documentation Française). Paris.

Oudin, F. (2009). Ethnologie du quotidien des "passionnés de moto". Construction d'un être au monde par l'investissement d'une machine. (Ethnologie). Paul-Verlaine, Metz.

Özkan, T., \& Lajunen, T. (2005). Why are there sex differences in risky driving? The relationship between sex and gender-role on aggressive driving, traffic offences, and accident involvement among young Turkish drivers. Aggressive Behavior, 31(6), 547-558.

Özkan, T., \& Lajunen, T. (2006). What causes the differences in driving between young men and women? The effects of gender roles and sex on young drivers' driving behaviour and selfassessment of skills. Transportation Research Part F: Traffic Psychology and Behaviour, 9(4), 269-277.

Özkan, T., Lajunen, T., Doğruyol, B., Yıldıım, Z., \& Çoymak, A. (2012). Motorcycle accidents, rider behaviour, and psychological models. Accident Analysis \& Prevention, 49, 124-132. https://doi.org/10.1016/j.aap.2011.03.009

630 Özkan, T., Lajunen, T., \& Summala, H. (2006). Driver Behaviour Questionnaire: A follow-up study. Accident Analysis \& Prevention, 38(2), 386-395. https://doi.org/10.1016/j.aap.2005.10.012

Parker, D., Reason, J. T., Manstead, A. S., \& Stradling, S. G. (1995). Driving errors, driving violations and accident involvement. Ergonomics, 38(5), 1036-1048.

Pfeffer, K., Fagbemi, H. P., \& Stennet, S. (2010). Adult pedestrian behavior when accompanying children on the route to school. Traffic Injury Prevention, 11(2), 188-193.

Pravossoudovitch, K. (2016). Hommes au volant, femmes au volant. L'influence des stéréotypes de sexe sur les comportements de conduite déclarés et effectifs. Aix-Marseille Université, Marseille.

Pravossoudovitch, K., Martha, C., Cury, F., \& Granié, M.-A. (2015). Sex and Age Differences in the Endorsement of Sex Stereotypes Associated with Driving. The Spanish Journal of Psychology, 18. https://doi.org/10.1017/sjp.2015.94

Reason, J., Manstead, A., Stradling, S., Baxter, J., \& Campbell, K. (1990). Errors and violations on the roads: a real distinction? Ergonomics, 33(10-11), 1315-1332. https://doi.org/10.1080/00140139008925335 
645 Recours, R., Souville, M., \& Griffet, J. (2004). Expressed motives for informal and club/asociationbased sports participation. Journal of Leisure Research, 36(1), 1-22.

Riva, G., Teruzzi, T., \& Anolli, L. (2003). The use of the Internet in Psychological research: Comparison of online and offline questionnaires. CyberPsychology \& Behavior, 6(1), 73-80. https://doi.org/10.1089/109493103321167983

650

Rutter, D. R., \& Quine, L. (1996). Age and experience in motorcycling safety. Accident Analysis \& Prevention, 28(1), 15-21. https://doi.org/10.1016/0001-4575(95)00037-2

Sakashita, C., Senserrick, T., Lo, S., Boufous, S., \& de Rome, L. (2014). The Motorcycle Rider Behavior Questionnaire: Psychometric properties and application amongst novice riders in Australia. Transportation Research Part F: Traffic Psychology and Behaviour, (22), 126-139.

Schmid Mast, M., Sieverding, M., Esslen, M., Graber, K., \& Jäncke, L. (2008). Masculinity causes speeding in young men. Accident Analysis \& Prevention, 40(2), 840-842. https://doi.org/10.1016/j.aap.2007.09.028

Simon, F., \& Corbett, C. (1996). Road traffic offending, stress, age, and accident history among male and female drivers. Ergonomics, 39(5), 757-780.

Stephens, A. N., Brown, J., de Rome, L., Baldock, M. R. J., Fernandes, R., \& Fitzharris, M. (2017). The relationship between Motorcycle Rider Behaviour Questionnaire scores and crashes for riders in Australia. Accident Analysis \& Prevention, 102, 202-212. https://doi.org/10.1016/j.aap.2017.03.007

Sullman, M., Taylor, J. (2010). Social desirability and self-reported driving behaviours: Should we be worried? Transportation Research Part F: Traffic Psychology and Behaviour, 13, 215-221. https://doi.org/10.1016/j.trf.2010.04.004

Sümer, N., Özkan, T., \& Lajunen, T. (2006). Asymmetric relationship between driving and safety skills. Accident Analysis \& Prevention, 38(4), 703-711.

Tom, A., \& Granié, M.-A. (2011). Gender differences in pedestrian rule compliance and visual search at signalized and unsignalized crossroads. Accident Analysis \& Prevention, 43(5), 1794-1801. https://doi.org/10.1016/j.aap.2011.04.012 
Tunnicliff, D.J., Watson, B., White, K., Hyde' M., Schonfeld, C., Wishart, D. (2012). Understanding the factors influencing safe and unsafe motorcycle rider intentions. Accident Analysis \& Prevention, 49, 133-141. https://doi.org/10.1016/j.aap.2011.03.012

675 Unger, R. K. (1979). Toward a redefinition of sex and gender. American Psychologist, 34(11), 10851094. https://doi.org/10.1037/0003-066X.34.11.1085

Unger, R. K., Hurtig, M. C., \& Pichevin, M. F. (1986). Pour une nouvelle définition du sexe et du genre. La Différence Des Sexes, 299-319.

Zhao, N., Mehler, B., Reimer, B., D’Ambrosio, L., Mehler, A., Coughlin, J. (2012). An investigation of the relationship between the driving behavior questionnaire and objective measures of highway driving behavior. Transportation Research Part F: Traffic Psychology and Behaviour, 15, 676-685. http://dx.doi.org/10.1016/j.trf.2012.08.001

Zuckerman, M. (1979). Sensation seeking: Beyond the Optimal Level of Arousal. Lawrence Erlbaum Associates, Hillsdale, New Jersey. https://doi.org/10.1002/9780470479216.corpsy0843

Zuckerman, M. (1994). Behavioural Expressions And Biosocial Bases of Sensation Seeking. Cambridge University Press, New York. 